\title{
OBLĘŻENIE ADRIANOPOLA PODCZAS I WOJNY BAŁKAŃSKIEJ (1912-1913)
}

Streszczenie. Każda wojna jest złem, niosąc śmierć, cierpienie, wypędzenie i spustoszenie. Nie inaczej było podczas dwóch wojen bałkańskich z lat 1912-1913, które z jednej strony cechowały się znaczną intensywnością i różnorodnością form prowadzenia działań militarnych, z drugiej zaś niebywałym okrucieństwem wymierzonym przeciwko cywilom. Celem artykułu jest przedstawienie warunków, w jakich przebiegała obrona Adrianopola podczas I wojny bałkańskiej. Aby to zrealizować, niezbędne stało się omówienie znaczenia militarnego twierdzy adrianopolskiej oraz przebiegu oblężenia, z uwzględnieniem sytuacji ludności cywilnej znajdującej się w obleganym mieście.

Słowa kluczowe: Adrianopol, I wojna bałkańska, Şükrü pasza, ludność cywilna

\section{Znaczenie militarne Adrianopola}

W 1912 r. Adrianopol (tur. Edirne, bułg. Odrin) był stolicą prowincji i ważnym ośrodkiem na szlaku prowadzącym z Europy do Stambułu. Położony u ujścia Tundży i Ardy do Maricy był kilkukrotnie oblegany, a tereny w jego pobliżu stały się miejscem wielu bitew ${ }^{1}$. Od $1361 \mathrm{r}$. Adrianopol znajdował się w granicach Imperium Osmańskiego, gdzie do czasu zdobycia Konstantynopola pełnił funkcję stolicy. Po tym czasie miasto zachowało uprzywilejowaną pozycję i posiadało nieformalny status „drugiej stolicy”. Znajdowały się tu dwa pałace sułtańskie i 40 meczetów, z których największą sławą cieszył się meczet Selima II².

1 П. Аървингов, Атаката на Одрин. Под осветлението на историята и изкуството, София 1931, s. 39-41.

2 Adryanopol, „Dziennik Poznański” 2013, nr 51, Dodatek, s. 2. 
Adrianopol był opasany murami obronnymi. Na początku XIX w. - w związku z wojną z Rosją (1829) - otoczono go umocnieniami polowymi i przekształcono w obóz warowny, który został rozbudowany podczas wojny rosyjsko-tureckiej w latach1877-1878³. W 1878 r. w momencie utworzenia państwa bułgarskiego i przesunięcia granicy państwowej, która przebiegała $24 \mathrm{~km}$ od centrum miasta, militarne znaczenie Adrianopola niepomiernie wzrosło. Z tego też powodu w 1909 r., pod kierunkiem niemieckich inżynierów, rozpoczęto modernizację umocnień, przekształcając miasto w twierdzę . Szeroki zakres inwestycji spowodowal, że w 1912 r. prace fortyfikacyjne nie zostały ukończone.

Pas umocnień Adrianopola rozciągał się na przestrzeni $35 \mathrm{~km}$ i obejmował główną pozycję obrony składającą się z 24 fortów wykonanych z cegły i kamienia, z których dwa posiadały kopuły pancerne. Usytuowano je na wzniesieniach i rozmieszczono w odległości $8-10 \mathrm{~km}$ od siebie i od 3 do $8 \mathrm{~km}$ od murów miasta. Były one wyposażone w broń maszynową, artylerię i łączność telefoniczną. Przed głównym pasem obrony rozbudowano pozycję przednią, opierając się na systemie transzei, a na przedpolu wykopano rowy o głębokości $4 \mathrm{~m}$ oraz ustawiono zapory z drutu kolczastego i improwizowane miny, tzw. fugasy. W północno-zachodnim sektorze 800-metrowy odcinek przedpola zalano wodą. $\mathrm{Na}$ rzekach przepływających przez twierdzę wybudowano mosty pontonowe, dzięki czemu obrońcy mogli szybko się przemieszczać w jej obrębie 5 . Załoga twierdzy dysponowała także 12 reflektorami, balonem obserwacyjnym służącym do korygowania ognia artylerii i dwoma radiostacjami ${ }^{6}$. Wszystko to powodowało, że twierdza cieszyła się opinią „niezdobytej”

Wspomniane rzeki dzieliły linie obronne na cztery sektory: północno-zachodni (między Maricą a Tundżą), wschodni (między Tundżą a Maricą), południowy (między Maricą a Ardą) i zachodni (między Ardą a Maricą) ${ }^{8}$. Naj-

${ }^{3}$ П. АъРвингов, op. cit., s. 41.

${ }^{4}$ Б. КүЮмЧАЖИев, Пленяването на коменданта на Одринската крепост на 13 март 1913 г., „Военноисторически сборник” 1983, брой 1, s. 97.

5 А. ПАстухов, Балканскал война 1912-1913 г2., [w:] Малье войны первой половинь ХХ века. Балканьи, сост. Б. Аозовский, Санкт Петербург 2003, s. 268.

${ }^{6}$ A. Vachkov, The Balkan War 1912-1913, Sofia 2005, s. 123-124.

7 J. LipKowski, Wojna na Batkanach. Przez naocznego świadka i uczestnika wojny, WarszawaLublin-Łódź-Kraków 1913, s. 158.

8 А. ПАСтуХОВ, op. cit., s. 269. 
większą wartość bojową miały umocnienia północno-zachodniej i zachodniej części twierdzy, podczas gdy te w południowej i wschodniej części nie zostały przygotowane z podobną dbałością.

W mieście rozlokowano silny garnizon składający się z jednostek IV Korpusu Armii, dwóch brygad kawalerii oraz sił przeznaczonych do obrony twierdzy. W skład tych ostatnich wchodziło pięć pułków artylerii ciężkiej, bataliony ciężkich karabinów maszynowych, inżynieryjny, kolejowy, budowlany, kompania telegraficzna, straż pożarna i oddział żandarmów. W mieście znajdowały się ponadto: szkoła podoficerska, szkoła żandarmerii, szpital wojskowy na 500 lóżek i warsztaty mundurowe. Ogółem garnizon liczył 10-15 tys. żołnierzy, z czego 6 tys. stanowiła załoga twierdzy'.

Eskalacja napięcia w stosunkach międzynarodowych spowodowała, że 24 września 1912 r. władze tureckie ogłosiły mobilizację w europejskiej części kraju. Dnia 6 października jednostki IV Korpusu Armii i kawalerii opuściły miasto, a cztery dni później dowództwo nad załogą twierdzy powierzono Mehmetowi Şükrü paszy ${ }^{10}$. W jego dyspozycji znalazły się, obok wspomnianych jednostek artylerii i oddziałów technicznych, dwie dywizje piechoty (dalej: DP) nizam - armii polowej (10 i 11), trzy DP redif - rezerwy („Edirne”, „Gümülcine” i „Babaeski”) oraz 4. pułk piechoty (dalej: pp). Zgromadzone siły liczyły łącznie 19 batalionów piechoty nizam i 30 batalionów piechoty redif. Ogółem liczba żołnierzy stanowiących załogę twierdzy wynosiła 1111 oficerów i 60139 szeregowych i podoficerów ${ }^{11}$. Obrońcy dysponowali 500 działami i 65 kartaczownicami. Twierdza była zaopatrzona w amunicję i żywność tak, aby załoga mogła samodzielnie prowadzić działania, przez co najmniej dwa miesiące ${ }^{12}$.

9 Войната между България и Туриия през 1912-1913 г., т. 5, Операцит около Одринската крепост, книга пврва, София 1930, s. 26.

${ }^{10}$ Şükrü pasza był absolwentem szkoły oficerskiej w Stambule i akademii wojskowej w Poczdamie. Cieszył się opinią wymagającego dowódcy, legitymującego się doświadczeniem bojowym nabytym w tłumieniu powstania ilindeńsko-preobrażenskiego w 1903 r. Ostatnio pełnił funkcję inspektora oddziałów rezerwowych (redif) i komendanta twierdzy dardanelskiej. F. AKTAŞ, Mehmet Şükrü pasa ve Edirne savunmasi, [w:] Edirne Eğitim. Dosya: 100.Yulında Balkan Savasları, ed. S. SAYIN, Edirne 2013, s. 31-32; Б. КҮЮмUАЖUЕВ, op. cit., s. 97.

11 E.J. ERICKSON, Defeat in Detail. Ottoman Army in the Balkans, 1912-1913, London 2003, s. 142 .

12 Войната между..., т. V, книга пьрва, s. 29. 
Utrzymanie twierdzy w Adrianopolu miało kluczowe znaczenie w tureckich planach obrony Tracji. Wynikało to z przyjęcia założenia, że wojska sułtana zmobilizują się później niż bułgarskie. Stąd też Mehmet Şükrü pasza przy pomocy podległych mu sił miał za zadanie osłaniać oddziały Armii Wschodniej gromadzące się na linii Adrianopol-Kirk Kilise. W praktyce miało to polegać na wiązaniu sił przeciwnika oraz wykonaniu uderzeń na skrzydła i tyły wojsk bułgarskich. Ponadto zgromadzone w Adrianopolu oddziały miały uniemożliwić Bułgarom przekroczenie Ardy i nie dopuścić do zamknięcia pierścienia okrążenia wokól twierdzy ${ }^{13}$.

Znaczenie Adrianopola dostrzegali także oficerowie bułgarskiego Sztabu Generalnego. Zgodnie z opracowanymi w latach 1909-1911 planami wojny armia bułgarska miała podjąć działania zaczepne i pokonać wojska tureckie w fazie ich koncentracji ${ }^{14}$. Ponieważ uznano, że zdobycie twierdzy może kosztować zbyt wiele ofiar, postanowiono ją blokować siłami jednej armii. W tym czasie pozostałe dwie armie miały pokonać przeciwnika i nacierać w kierunku Stambułu. Oddziały blokujące twierdzę miały zatem pełnić rolę pomocniczą i do czasu zakończenia głównej bitwy ograniczyć się do „neutralizacji” zagrożenia ze strony załogi twierdzy w Adrianopolu ${ }^{15}$.

Zadanie jej izolacji otrzymała bułgarska 2. Armia dowodzona przez gen. lejt. Nikołę Iwanowa ${ }^{16}$. W jej składzie znajdowały się: 8 . Tundżańska DP, 9. Plewneńska DP, 1. Brygada Piechoty (dalej: BP) ze składu 3. Bałkańskiej DP, Oddział Chaskowski ${ }^{17}$, Zbiorcza Brygada Kawalerii, 2. dywizjon artylerii hau-

13 E.J. ERICKSON, op. cit., s. 185.

${ }^{14}$ Na skutek podpisania $12 \mathrm{~V} 1912$ r. serbsko-bułgarskiej konwencji wojskowej i przeprowadzonych rozmów sztabowych, opracowany w 1911 r. plan wojny uległ istotnym zmianom w sferze wykonawczej. Co do ogólnej koncepcji prowadzenia działań militarnych pozostał jednak bez zmian. Szerzej na ten temat: И. КРиворов, Плановете на воюващите страни за Пгрвата балканска война 1912-1913 г., „Военноисторически сборник” 2006, брой 4, s. 13.

15 Аиректива Но 1 по Аействащата Армия за задачите на 1-ва, 2-ра и 3-а Армия през пврвия ден от войната, Стара Загора, 4 октомври 1912 г., dok. nr 272, [w:] Българска военна история. Подбрани извори и документи, т. 2, red. Х. ХРистов, София 1984, s. 489.

16 Bułgarski generał ukończył Mikołajewską Akademię Sztabu Generalnego w Petersburgu, a w latach 1896-1899 zajmował stanowisko ministra wojny w rządzie Konstantina Stoiłowa. Jako ochotnik brał dział w wojnie rosyjsko-tureckiej 1877-1878 i wojnie serbsko-bułgarskiej 1885 r., А. ЦУРАКОВ, Енщиклопедия правителствата на Бблгария. Хронология на политическия живот 1879-2005, София 2005, s. 73.

17 Odział Chaskowski został utworzony na bazie 2. BP ze składu 2. Trackiej DP i składał się z ośmiu i $1 \frac{2}{2}$ batalionów piechoty, dziewięciu baterii artylerii i szwadronu kawalerii - Войната междy 
bic, 2. kompania taborów i 1. oddział aeronautyczny. W sumie 66 i 3/4 batalionów piechoty, dziewięć szwadronów kawalerii, 42 baterie artylerii ${ }^{18}$. Ogółem w składzie jednostek armii znajdowało się: 67831 żołnierzy, 198 dział i 68 kartaczownic ${ }^{19}$.

\section{Przebieg oblężenia}

Dnia 18 października 1912 r. o godz. 12.00 oddziały bułgarskiej 2. Armii przekroczyły granicę, nie napotykając większego oporu ze strony tureckiej straży granicznej. W trakcie następnych czterech dni, pomimo trudnych warunków terenowych będących efektem długotrwałych opadów deszczu, siły główne armii zbliżyły się do Adrianopola ${ }^{20}$. W tym czasie operujący we wschodnich Rodopach Oddział Chaskowski opanował Kyrdżali ${ }^{21}$, zabezpieczając tym sposobem prawą flankę armii i przerywając połączenie komunikacyjne łączące Adrianopol z Salonikami.

Cztery dni później (22 października), w związku z bitwą pod Kirk Kilisse, garnizon twierdzy otrzymał rozkaz zaatakowania jednostek bułgarskiej 1. Armii znajdujących się na północny wschód od miasta. Natarcie wykonane zostało siłami trzech dywizji piechoty. Bułgarskie oddziały (3. i 10. DP) powstrzymały jednak ich atak pod Kayapą, po czym zmusiły do odwrotu ${ }^{22}$.

W następstwie przegranej bitwy pod Kirk Kilisse i wycofania się wojsk tureckich na linię Pınarhisar-Lüleburgaz sytuacja obrońców twierdzy uległa pogorszeniu. Utracono styczność z oddziałami Armii Wschodniej, a 27 października na skutek zajęcia przez jednostki 1 . Armii bułgarskiej stacji Babaeski przerwane zostało połączenie kolejowe łączące Adrianopol ze Stambułem ${ }^{23}$. Dwa

България и Туриия през 1912-1913 г., т. 5: Операцит около Одринската крепост, книга втора, София 1930, s. 1072.

18 Войната между..., т. 5, книга първа, s. 48.

19 Ibidem, книга втора, s. 1073.

20 А. Михов, Балканската война 1912-1913. Военните действия в Тракия до Чаталджанското примирие, София 1914, s. 42-44.

${ }_{21}$ Телеграма от командващия 2-ра Армия генерал-лейтенант Иванов до командващия 1-ва Армия за освобождането на Кгрджали, Тьрново Сеймен, 9 октомври 1912 г., dok. nr 282, [w:] Българска военна..., s. 500.

22 А. Христов, Кратка история на Освободителната война 1912-1913 година, София 1946, s. 278-280.

${ }_{23}$ А.А. РяБинин, Балканскал война, [w:] Малье войныс.., s. 171. 
dni później (29 października), w momencie rozpoczęcia bitwy pod Lüleburgaz, obrońcy Adrianopola podjęli próbę przerwania blokady. Znaczne siły (18 batalionów piechoty) opuściły twierdzę i zaatakowały oddziały 8. i 9. DP. W wyniku dwudniowych walk musiały się jednak wycofać, ponosząc duże straty ${ }^{24}$.

Zwycięstwo pod Lüleburgaz i bezładny odwrót wojsk tureckich skłoniły dowództwo bułgarskie do podjęcia decyzji o zamknięciu pierścienia okrążenia twierdzy, co nastąpiło 31 października ${ }^{25}$. Siły zgromadzone wokół Adrianopola były jednak niewystarczające do jego zdobycia. Szczególnie odczuwano brak ciężkiej artylerii niezbędnej do zniszczenia fortyfikacji otaczających miasto. $\mathrm{Z}$ tego też powodu Bułgarzy ograniczyli się do jego blokady. Wynikało to również ze stanowiska Rosji, która zgłosiła pretensje do terenów położonych wokół Adrianopola. Dopiero wycofanie na początku listopada 1912 r. rosyjskich zastrzeżeń umożliwiło Bułgarom podjęcie zdecydowanych działań ${ }^{26}$.

Wykorzystując wcześniejsze ustalenia powzięte podczas rozmów sztabowych, które przewidywały możliwość wzmocnienia wojsk bułgarskich walczących w Tracji jednostkami serbskimi, Bułgaria zwróciła się do rządu w Belgradzie o pomoc. Prośba ta została uwzględniona i pod Adrianopol skierowano 2. Armię w składzie dwóch dywizji piechoty ${ }^{27}$. Wysłane oddziały liczyły 47275 żołnierzy i 72 działa. Pod względem operacyjnym siły dowodzone przez gen. Stepę Stepanovića ${ }^{28}$ podporządkowane zostały gen. Iwanowowi.

Przybycie oddziałów serbskich w połowie listopada 1912 r. spowodowało reorganizację wojsk oblegających twierdzę. Północno-zachodni sektor został odsadzony przez serbską DP „Timok” I wezwania i bułgarski 55. pp, zachodni przez serbską DP „Dunaj” II wezwania, wschodni przez nowo sformowaną 11. DP i 2. BP ze składu 8. Tundżańskiej DP, a sektor południowy przez 1. i 3. BP ze składu 8. DP ${ }^{29}$.

${ }^{24}$ R.C. Hall, The Balkan Wars 1912-1913. Prelude to the First World War, London-New York 2005, s. 41.

${ }^{25} \mathrm{Ibidem}$. W literaturze podawana jest także data 9 listopad - vide: E.J. ERICKSON, op. cit., s. 144.

${ }^{26}$ И. Фичев, Балканската война 1912-1913. Преживелици, бележки и документи, София 1940, s. 86-87.

27 Войната между България и Туриия през 1912-1913 г., т. 6: Аействията на Западния операционен театьр, София 1935, s. 197.

${ }^{28}$ Serbski generał był absolwentem Akademii Wojskowej w Belgradzie. Brał udział w wojnach z Imperium Osmańskim w latach 1876 i 1877-1878 oraz wojnie serbsko-bułgarskiej 1885 r. W latach 1908 i 1911-1912 pełnił funkcję ministra wojny - vide: Р. БојевИћ, Војвода Cmena Cmenaнoвић 1856-1929, Чачак 2006, s. 7-15.

29 A. VACHKOV, op. cit., s. 126. 
Do początków grudnia walki o Adrianopol charakteryzowały się niewielką intensywnością, przy czym aktywniejszą stroną byli oblężeni, którzy nękali oblegających wypadami. Największy z nich miał miejsce 9-11 listopada i został przeprowadzony siłami 10 batalionów piechoty w sektorze północno-zachodnim na styku oddziałów serbskich i bułgarskich ${ }^{30}$. Obie strony prowadziły także ostrzał artyleryjski zajmowanych przez przeciwnika pozycji. W efekcie tych działań, do czasu zawarcia rozejmu Bułgarzy stracili 672 żołnierzy, 3497 zostało rannych, a 249 uznano za zaginionych. Straty Serbów wyniosły w tym samym czasie 126 zabitych i 673 rannych żołnierzy ${ }^{31}$.

Godnym odnotowania wydarzeniem w tym okresie było pierwsze na kontynencie europejskim bojowe wykorzystanie samolotów. Dnia 29 października 1912 r. załoga bułgarskiego samolotu „Albatros” w składzie por. Radul Milkow i por. Prodan Tarakczijew dokonała rozpoznania pozycji tureckich, a dzień później inna załoga dokonała pierwszego ataku bombowego ${ }^{32}$.

Wynegocjowane 3 grudnia 1912 r. zawieszenie broni spowodowało zaprzestanie walk ${ }^{33}$. Turcy rozejm wykorzystali na naprawę umocnień i rozbudowę linii obronnych. W celu podniesienia ducha i podtrzymania woli oporu, sułtan nadał komendantowi twierdzy tytuł gazi (bohatera wojny za wiarę), awansował na stopień ferika (gen. lejt.) oraz odznaczył orderem Medjidie I klasy ${ }^{34}$.

Po drugiej stronie frontu specjalna komisja pod przewodnictwem gen. Iwanowa oszacowała możliwości zdobycia twierdzy i wydała w tej sprawie pozytywną opinię $^{35}$. Przyjęte podczas jej obrad wnioski posłużyły do sformułowania zamiaru dowódcy 2 . Armii ${ }^{36}$ oraz przygotowania pozostałych dokumentów sztabowych.

30 Б. РАтковић, М. Ђуришић, С. Скоко, Србија и Црна Гора у Балканским ратовима 1912-1913, БеограА 1972, s. 143; E.J. ERICKSON, op. cit., s. 144.

31 А. ВАчЕВА, Полковник Никола Жеков в подкрепа на истината за Одринската епопея 1913 ., „Военноисторически сборник” 2005, брой 1, s. 53.

32 Й. МилАнов, Въздушните сили на България през войните 1912-1945, София 2008, s. 31-33.

33 Протокол за сключване на примирие с Туриия и започване на преговори за мир в Аондон, ЧаталАжа, 20 ноември 1912 г., dok. nr 313, [w:] Българска военна..., s. 525-526.

${ }^{34}$ E.J. ERICKSON, op. cit., s. 275.

${ }^{35}$ Протокол на комисията под председателството на командващия 2-ра Армия генераллейтенант Никола Иванов за най-подходящия начин за овладяване на Одринската крепост, Свилен[граА], 9, 10, 11 декември 1912 г., dok. nr 318, [w:] Българска военна..., s. 535-537.

${ }^{36}$ Свображениян на командващия 2-ра Армиягенерал-лейтенант Никола Иванов за овладяване на Одринската крепост и направлението на главния удар, СвиленграА, 20 декември 1912 г., dok. nr 322, [w:] Българска военна..., s. 541-544. 
Walki zostały wznowione 3 lutego 1913 r. Wbrew oczekiwaniom do szturmu twierdzy jednak nie doszło. Bułgarskie dowództwo oczekiwało jeszcze na wyniki negocjacji, mających na celu dobrowolne przekazanie Adrianopola przez stronę turecką. Ich fiasko spowodowało na początku marca podjęcie decyzji o szturmie twierdzy ${ }^{37}$.

Główne uderzenie miało zostać wykonane we wschodnim sektorze siłami 2. BP ze składu 8. Tundżańskiej DP przy wsparciu 11. DP oraz 2. BP ze składu 2. Trackiej DP, 1. BP ze składu 3. Bałkańskiej DP i 3. BP ze składu 4. Presławskiej DP, które zostały skierowane pod Adrianopol z linii Çatalcy. Całością sił na tym odcinku liczących 52 bataliony piechoty dowodził doświadczony inżynier wojkkowy gen. mjr Georgi Wazow ${ }^{38}$. W pozostałych sektorach oddziały serbskie i bułgarskie miały wykonać uderzenia pomocnicze w celu związania walką przeciwnika i uniemożliwienia mu przerzucenia rezerw na zagrożony odcinek ${ }^{39}$. Aby zapewnić powodzenie ataku, całą artylerię, z wyjątkiem sześciu baterii artylerii polowej, zgrupowano w sektorze wschodnim. Dodatkowo w połowie lutego zgrupowanie artylerii na tym odcinku frontu wzmocniono czterema bateriami haubic $120 \mathrm{~mm}$ i dwoma bateriami armat $150 \mathrm{~mm}$ przybytymi z Serbii ${ }^{40}$.

Atak zaplanowano na 25 marca $^{41}$. Poprzedzony został ostrzałem artyleryjskim, który rozpoczął się 24 marca o godzinie 13.00 i trwał do godziny 20.00, z wyjątkiem sektora północno-zachodniego, gdzie zakończył się o godz. $23.30^{42}$. Rankiem między godziną 3.30 a 4.00 piechota zaatakowała pozycje tureckie. We wschodnim sektorze Bułgarzy uzyskali powodzenie i zmusili obrońców do wycofania się na główną pozycję obronną złożoną z fortów okalających mia-

37 Г. МАрков, България в Балканския съюз срешу Османската империя, 1912-1913 г., София 1989 , s. 313.

38 Заповед Но 92 по Аействащата Армия за възлагане командуването на обединените 1-ва и 3-а Армия на генерал-лейтенант Васил Кутинчев, а генерал-майор Георги Вазов за началник на източния сектор на Одринската крепост, Аимотика, 17 януари 1913 г., dok. nr 328, [w:] Българска военна..., s. 560.

39 Г. МАРКОВ, op. cit., s. 314.

40 Б. РАТКОвИЋ, М. ЂУришић, С. СКОкО, ор. cit., s. 149.

41 Заповед Но 58 командвашия 2-ра Армия генерал-лейтенант Никола Иванов за атака и обладаването на предфронтовата полоса на Одринската крепост, Оршакчи, 10 март 1913 г., dok. nr 344, [w:] Българска военна..., s. 579-580.

42 Войната между..., т. 5, книга втора, s. 821-827. 
sto. W sektorach południowym zachodnim i północno-zachodnim oddziały bułgarskie i serbskie zdołały przesunąć się o 400-500 m, po czym zostały zatrzymane ${ }^{43}$.

Natarcie zostało wznowione wraz ze wschodem księżyca, po krótkim półgodzinnym przygotowaniu artyleryjskim. Dnia 26 marca o godz. 1.50 żołnierze 10. Rodopskiego pp zdobyli fort Bağlarönü, a wkrótce potem żołnierze 23. Szipczeńskiego pp zagarnęli fort Ayvaz Baba. Między godz. 6.45 a 8.45 pozostałe forty we wschodnim sektorze znalazły się w rękach Bułgarów. Powodzenie uzyskało także natarcie prowadzone na pozostałych odcinkach ${ }^{44}$.

O godz. 9.30 pierwsze oddziały bułgarskie (23. pp) i serbskie (20.pp) wdarły się do miasta. Sytuacja obrońców stała się krytyczna. Część żołnierzy tureckich zaprzestała walki i złożyła broń, inni bronili się w domach. W tej sytuacji komendant twierdzy nakazał wysadzić most kolejowy, składy amunicji i obiekty wojskowe, które mogłyby być przydatne dla wroga. Zniszczono także urządzenia zapewniające łączność radiową ze Stambułem i dokumenty sztabowe. W kilku dzielnicach miasta podłożono ogień. Wkrótce potem, nie widząc szans obrony, Şükrü pasza wysłał parlamentarzystów w celu wynegocjowania warunków kapitulacji twierdzy. W tym samym czasie na ulicach miasta pojawiła się bułgarska kawaleria. Dnia 26 marca o godz. 13.30 twierdza w Adrianopolu skapitulowała, a w forcie Hidılık, gdzie przebywał komendant obrony, podniesiono białą flagę ${ }^{45}$. W czasie trwającego trzy dni szturmu zginęło 1289 żołnierzy bułgarskich, a 6626 zostało rannych. Straty oddziałów serbskich były niższe i wynosiły 274 zabitych i 1167 rannych $^{46}$.

Ogółem w czasie walk o twierdzę, według Richarda C. Halla, Bułgarzy stracili 18282 żołnierzy, a Serbowie około 8 tys. ${ }^{47} \mathrm{~W}$ wyniku oblężenia, zginęło lub zmarło także ponad 13 tys. żołnierzy tureckich, a 28,5 tys. dostało się do niewoli ${ }^{48}$. Wśród tych ostatnich, jak donosiła prasa, znalazło się 16 paszów,

43 Н. Иванов, Балканската война 1912-1913. Аействията на II Армия. Обсада и атака на Одринската крепост, София 1924, s. 301.

44 E.J. ERICKSON, op. cit., s. 279-280.

45 H. ИвАНОВ, op. cit., s. 308.

46 A. BAYEBA, op. cit., s. 53.

47 R.C. HaLL, op. cit., s. 90.

48 Türk Silahl Kuvvetleri Taribi Osmanlı Devri Balkan Harbi (1912-1913) II nci Cilt 3 ncü Kısım Edirne Kalesi Etrafindaki Muharebeler, Ankara 1993, s. 471. Podobną liczbę jeńców (powyżej 
12 generałów, czterech wyższych urzędników oraz 63 niemieckich oficerów kontraktowych, 13 rumuńskich i kilku Belgów ${ }^{49}$. W ręce zwycięzców trafiło 413 armat, 46 kartaczownic, 12236 karabinów i ponad $10 \mathrm{mln}$ nabojów ${ }^{50}$.

W tym miejscu kilka słów należy poświęcić tureckim jeńcom. Mimo przyjęcia przez Bułgarię zobowiązań wynikających z IV konwencji haskiej z 1907 r., traktowano ich w różny sposób. Z jednej strony bułgarskie władze z szacunkiem odniosły się do Şükrüa paszy i wyższych oficerów, którym zapewniono odpowiednie warunki pobytu ${ }^{51}$. Z drugiej zaś odnotowano wiele przypadków rozstrzeliwania żołnierzy tureckich po wzięciu do niewoli, a nawet jeszcze $\mathrm{w}$ trakcie walk ${ }^{52}$. Jeńcy często koczowali pod gołym niebem, bez jedzenia, żywiąc się korą z drzew i żując skórę z butów ${ }^{53}$. Najgorszą sławą cieszył się obóz w Sarayiçi (ob. część Adrianopola) ulokowany na wyspie Tunca. Przebywało w nim ok. 20 tys. jeńców, z czego co najmniej połowa straciła życie z powodu głodu, zimna, chorób zakaźnych i okrutnego traktowania ${ }^{54}$. Sytuacja jeńców w innych obozach nie była lepsza.

\section{Sytuacja ludności cywilnej}

W tle walk o twierdzę rozgrywał się dramat ludności cywilnej. W przededniu wybuchu wojny liczba mieszkańców miasta wynosiła ok. 75 tys. osób. Wielowiekowa historia powodowała, że jego populacja była zróżnicowana pod względem etnicznym i religijnym. Najliczniejszą grupą stanowili muzułmanie, szacowani na ok. 35 tys. Oprócz nich w mieście mieszkało: 18863 Greków,

33 000) podają także bułgarscy autorzy nр. С.А. Пенков, Развитие на действията. Аозенградско срешно сражение, [w:] Кратка военна история на Бблгария 681/1945, София 1977, s. 265.

${ }^{49}$ Wojna, „Dziennik Poznański” 1913, nr 74, s. 2.

50 C.A. ПЕнКОв, op. cit., s. 265.

${ }_{51}$ Tureckiemu generałowi oddano szablę, a w czasie pobytu w niewoli miał do dyspozycji samochód, İ. Alp, 1912-1913 Balkan Savaşlarinda Edirne’nin Sükûtu ve Yaşanan Faciâlar, „Karadeniz Araştırmaları" 2018, nr XV/60, s. 12.

52 The Report of the International Commission to Inquire into the Causes and Conduct of the Balkan Wars, Washington 1914, s. 216.

53 Ibidem, s. 326.

54 O.D. MACar, Epidemic Diseases on the Thracian Front of the Ottoman Empire during the Balkan Wars, [w:] War and Nationalism. The Balkan Wars, 1912-1913, and Their Sociopolitical Implications, ed. M.H. YAVUZ, I. BLUMI, Salt Lake City 2013, s. 290. 
13703 Żydów, 4004 Ormian i 2121 Bułgarów. Każda z tych grup miała własne miejsca kultu, szkoły i szpitale, a ich głównym zajęciem były handel, rzemiosło i rolnictwo ${ }^{55}$.

Niebawem (3 października) władze tureckie zarządziły częściową ewakuację ludności cywilnej, głównie kobiet, dzieci, inwalidów i cudzoziemców ${ }^{56}$. Jednocześnie ponad 200 Bułgarów, głównie nauczycieli i duchownych, zostało prewencyjnie aresztowanych oraz wywiezionych w głąb Azji Mniejszej5 ${ }^{57}$ W miejsce osób, które wyjechały, pojawiali się jednak mieszkańcy z okolicznych miejscowości, którzy szukali schronienia. Stąd też szacuje się, że w czasie oblężenia w granicach miasta mogło znajdować się nawet ponad 100 tys. cywili ${ }^{58}$.

Ze względu na rolniczy charakter regionu i fakt, że Adrianopol był centrum handlu zbożem, w mieście zgromadzono jego pokaźne zapasy, zarówno w państwowych magazynach, jak i w rękach prywatnych. W swoim czasie władze miejskie uprzedziły mieszkańców, aby zrobili zapasy zboża na co najmniej cztery miesiące. Nie brakowało także zwierząt przeznaczonych do uboju. Od początku w mieście pojawiły się natomiast niedobory soli, cukru, drewna i furażu, co spowodowało, że cena tych artykułów w listopadzie 1912 r. wzrosła od pięciu do dziesięciu razy 59 .

Ważnym problemem stała się również kwestia zachowania odpowiedniego stanu sanitarno-higienicznego i zapewnienia potrzebującym opieki medycznej. Zadania te realizowano na bazie stałych szpitali. Oprócz tego staraniem organizacji, stowarzyszeń oraz konsulów Francji i Wielkiej Brytanii powstało kilka szpitali polowych ${ }^{60}$.

W pierwszych dniach oblężenia walki toczyły się na przedpolach twierdzy, stąd też ich skutki nie były dotkliwe dla ludności cywilnej. Sytuacja uległa

55 Türk Silablı..., s. 22.

56 S.T. WASTI, The 1912-13 Balkan Wars and the Siege of Edirne, „Middle Eastern Studies” 2004, vol. 40, no. 4, s. 64 .

57 С. ЕцАъРОв, Една история за Балканската война, събрана през десетилетията, „Военноисторически сборник" 2007, брой 3, s. 4; F. ADANIR, Non-Muslims in the Ottoman Army and the Ottoman Defeat in the Balkan War of 1912-1913, [w:] A Question of Genocide. Armenians and Turks at the End of the Ottoman Empire, eds R.G. SunY, F.M. GÖçEK, N.M. NAIMARK, Oxford 2011, s. 121.

58 A. LEVY, The Siege of Edirne (1912-1913) as Seen by a Jewish Eyewitness: Social, Political and Cultural Perspectives, [w:] Jews, Turks, and Ottomans: A Shared History, Fifteenth Through the Twentieth Century, ed. IDEM, Syracuse-New York 2002, s. 156.

59 İ. AlP, op. cit., s. 5.

60 Войната между..., т. 5, книга първа, s. 36. 
zmianie 21 listopada, kiedy to pierwszy pocisk spadł na zamieszkałą część miasta. Od tej pory bombardowanie było kontynuowane, aż do chwili zawarcia rozejmu. W tym czasie zniszczono 333 domy, 13 osób zostało zabitych, a 53 odniosło rany ${ }^{61}$. Nikt nie mógł czuć się bezpiecznie, zaś ludność cywilna szukała schronienia, co przy drewnianej zabudowie miasta nie było sprawą łatwą. Ludzie gromadzili się w miejscach kultu religijnego i budynkach szkolnych. Jednym z takich miejsc był przytułek pw. Matki Boskiej z Lourdes, gdzie schroniło się ponad 200 osób, głównie chrześcijan, w tym konsulowie obcych państw ${ }^{62}$. W bardzo ciężkim położeniu ludność znalazła się cztery dni po zamknięciu okrążenia przez oddziały bułgarskie, kiedy uszkodzony został wodociąg dostarczający wodę do miasta ${ }^{63}$. Od tej pory obrońcy twierdzy i ludność cywilna byli zmuszeni korzystać z wody pochodzącej z rzek.

Ogłoszone zawieszenie broni było tylko krótkim wytchnieniem dla mieszkańców miasta. Koniec rozejmu oznaczał wznowienie ostrzału artyleryjskiego. Tylko pierwszego dnia w jego wyniku zginęło 20 cywili, 20 zostało rannych, zaś 53 domy uległy zniszczeniu. Uszkodzono m.in. meczet Selima II i szpital miejski. W mieście wybuchły pożary ${ }^{64}$.

Coraz większym zmartwieniem był także brak żywności, której ceny gwałtownie wzrosły. W najgorszym położeniu znaleźli się zbiegowie z pobliskich miejscowości, którzy uciekając w popłochu, brali tylko to, co znajdowało się pod ręką. Ci otrzymywali żywność z zapasów miejskich, ale w bardzo ograniczonych ilościach, przy czym asortyment wydawanych produktów ograniczał się do chleba i sera. Starając się poprawić sytuację aprowizacyjną, w styczniu 1913 r. gubernator prowincji zarządził rekwizycję prywatnych zapasów zboża, pozwalając właścicielom zachować na własne potrzeby po $40 \mathrm{~kg}$ na każdego członka rodziny ${ }^{65}$. Działania te przyniosły tylko chwilową poprawę w zaopatrzeniu. Po 20 lutego zmniejszono dzienną rację chleba, wypiekanego głównie z kukurydzy, prosa, słomy i popiołu, do $75 \mathrm{~g}$ na osobę ${ }^{66}$.

Coraz większym problemem było również utrzymanie stanu sanitarno-higienicznego. Z powodu braku środków higieny i czystej wody zaczęły roz-

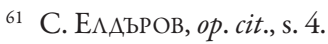

62 W zdobytym Adryanopolu, „Dziennik Poznański” 1913, nr 99, Dodatek, s. 2.

63 Войната между..., т. 5, книга първа, s. 34.

64 İ. Alp, op. cit., s. 7.

${ }^{65}$ Woblężonem mieście, „Dziennik Poznański” 1913, nr 40, Dodatek, s. 1.

66 İ. AlP, op. cit., s. 8.
} 
przestrzeniać się choroby zakaźne. Pierwsze zachorowania odnotowano już w drugiej połowie listopada 1912 r. Dzięki wysiłkom lekarzy i władz miejskich udało się jednak powstrzymać rozwój epidemii ${ }^{67}$. Mimo to, za sprawą przedłużającego się oblężenia i srogiej zimy, śmiertelność wśród ludności cywilnej była wysoka. Najczęstszym powodem zgonów były choroby płuc i wyczerpanie głodowe ${ }^{68}$.

Szczególnie ciężkie chwile ludność cywilna przeżyła podczas zapoczątkowanego 24 marca 1913 r. szturmu miasta, kiedy to w ostatniej fazie walki przeniosły się na ulice miasta. Po wdarciu się do miasta oddziałów bułgarskich i serbskich część tureckich żołnierzy rozbiegła się, szukając schronienia wśród rodaków. Ich odszukaniem zajęli się żołnierze bułgarscy. Nie obeszło się przy tym bez krwawych utarczek. Towarzyszyły temu także liczne przypadki grabieży i gwałtów. W relacjach muzułmańskich mieszkańców miasta przyjęło to postać trwającej trzy dni „orgii zniszczenia”. Strona bułgarska deprecjonowała te wydarzenia, tłumacząc je prowadzoną akcję przeczesywania miasta w celu wyłapania ukrywających się żołnierzy tureckich ${ }^{69}$.

Wydarzenia z Adrianopola stały się przedmiotem śledztwa prowadzonego przez członków międzynarodowej komisji Fundacji Carnegiego. Zebrali oni wiele świadectw świadczących o tym, że żołnierze bułgarscy w momencie wkroczenia do miasta plądrowali ,jak szaleńcy przy akompaniamencie krzyków, ciosów i bluźnierstw"70. Sprawcami grabieży byli także miejscowi Grecy, a w pewnym stopniu także Żydzi i Ormianie. Motłoch ogołocił praktycznie wszystkie budynki publiczne, nie oszczędzając meczetów. Atakowano także prywatne domy. Aby położyć temu kres, władze wojskowe skierowały na ulice patrole, co początkowo przyniosło ograniczone efekty ${ }^{71}$. Względny porządek w mieście udało się przywrócić dopiero po trzech dniach ${ }^{72}$.

${ }^{67}$ Przypadki tyfusu, cholery i duru brzusznego zdiagnozowano u ok. 7000 osób, z czego ok. 1200 było hospitalizowanych, zaś 91 osób zmarło, O.D. MACAR, op. cit., s. 289.

${ }^{68}$ The Report of the International..., s. 111.

${ }^{69}$ Vide: relacja P.N. DASKALOWA zamieszczona w „Kölnische Zeitung” i przedrukowana w polskojęzycznej prasie pt. $W$ zdobytym Adryanopolu..., s. 2 .

70 The Report of the International..., s. 111.

7126 III 1913 r. dowódca 2. Armii wyznaczył na komendanta miasta gen. mjr. Waklina Nałkowa Cerkowskiego, a na dowódcę garnizonu gen. mjr. Georgia Wazowa, Телеграма командващия 2-ра Армия до штаба Действащата Армия за предаването на Шукри паша и за организаето на административната власт в Одрин, Оршакчи, 13 март 1913 г., dok. nr 348, [w:] Българска военна..., s. 582.

${ }^{72}$ The Report of the International..., s. 114-116. 
Delegaci wojujących stron podpisali 30 maja 1913 r. w Londynie traktat pokojowy w wyniku, którego Adrianopol znalazł się w granicach Bułgarii. Zdobycz ta była jednak krótkotrwała i już 22 lipca tego roku - wykorzystując II wojnę bałkańską - Turcy zajęli miasto, które pozostaje w granicach ich państwa po dzień dzisiejszy.

\section{Zakończenie}

Z wojskowego punktu widzenia szturm Adrianopola należy do nielicznych przykładów zdobycia silnie ufortyfikowanej twierdzy w krótkim czasie. Było to z jednej strony dowodem zdolności bojowych i morale żołnierzy bułgarskich ${ }^{73}$ oraz serbskich, zaś z drugiej - skutkiem umiejętnie przeprowadzonej blokady i oblężenia, które podkopały wolę walki tureckich żołnierzy.

Upadek twierdzy w Adrianopolu miał przy tym istotny wpływ na przebieg drugiej fazy I wojny bałkańskiej i praktycznie zakończył działania zbrojne na froncie bułgarsko-tureckim. Zdobycie fortecy wydatnie przyspieszyło zwycięski koniec konfliktu, którego owoce zostały później zmarnowane z powodu ambicji bułgarskiego monarchy ${ }^{74}$.

Z punktu widzenia Turków obrona twierdzy urosła do symbolu oporu, wierności i poświęcenia. To również okrutna lekcja, która pozostawiła głębokie ślady w świadomości narodu tureckiego, o czym świadczą różne formy jej upamiętnienia (pomniki, cmentarze) ${ }^{75}$ i pielęgnowana pamięć o 160 -dniowej obronie miasta.

Problem ten nie sprowadza się tylko do wątku tureckiego. Walki o Adrianopol spotkały się bowiem z żywym zainteresowaniem muzułmanów na całym świecie, pobudzając ich do wysiłku na rzecz zorganizowania pomocy współwyznawcom. Miały również wpływ na działania zmierzające do uzyskania przez nich emancypacji narodowej i religijnej.

${ }^{73}$ Wydarzenie to zostało upamiętnione w publicystyce i poezji bułgarskiej oraz stało się inspiracją do powstania wielu obrazów o tematyce batalistycznej i rodzajowej, JSZ [J. SZEPIETOWSKA], Adrianopol, [w:] Leksykon tradycji butgarskiej, red. A. NAUMOw, Warszawa 2011, s. 12.

7429 VI 1913 r. wybuchła II wojna bałkańska w wyniku, której Bułgaria straciła większość uzyskanych zdobyczy terytorialnych.

75 Przykładem może być tzw. Kamień Zemsty wzniesiony w 1939 r. w Havsa w celu upamiętnienia masakry ludności muzułmańskiej, E. KILIÇ, The Balkan war (1912-1913) and visions of the future in Ottoman Turkish literature, Leiden 2015, s. 73. 
Los twierdzy w Adrianopolu przykuwał uwagę także na zachodzie Europy, budząc sympatię dla obrońców i zamkniętych w murach twierdzy mieszkańców. W tym miejscu trzeba jednak stwierdzić, że mimo podejmowanych działań ze strony tureckich historyków wątki ludzkie opisywanych wydarzeń nie przebiły się do świadomości „ludzi cywilizacji Zachodu”. Co prawda, przywołane fakty są znane gronu historyków zajmujących się problematyką Bałkanów, ale nikt nie przejawia zainteresowania ich upowszechnianiem, jako że burzą pielęgnowane przez lata stereotypy kulturowe.

\section{BIBLIOGRAFIA}

\section{Źródła drukowane}

The Report of the International Commission to Inquire into the Causes and Conduct of the Balkan Wars, Washington 1914.

Българска военна история. Подбрани извори и документи, т. 2, red. Х. Христов, София 1984 (Balgarska voenna istoria. Podbrani izvori i dokumenti, t. 2, red. H. Hristov, Sofia 1984).

Войната между България и Туриия през 1912-1913 г., т. 5: Операчит около Одринската крепост, книга 1 и 2, София 1930; т. 6: Аействията на Западния операчионен театър, София 1935 (Voynata mezhdu Bulgaria i Turtsia prez 1912-1913 g., t. 5, Operatsit okoto Odrinskata krepost, kniga 1 i 2, Sofia 1930; t. 6: Deystviyata na Zapadnia operatsionen teatar, Sofia 1935).

\section{Prasa}

„Dziennik Poznański” 1913.

\section{Wspomnienia}

Lipkowski J., Wojna na Batkanach. Przez naocznego świadka i uczestnika wojny, Warszawa-Lublin-Łódź-Kraków 1913.

Иванов Н., Спомени 1861-1918, книга втора, София 1997 (Iwanow N., Spomieni 1861-1918, kniga vtora, Sofija 1997). 


\section{Opracowania}

Adanir F., Non-Muslims in the Ottoman Army and the Ottoman Defeat in the Balkan War of 1912-1913, [w:] A Question of Genocide. Armenians and Turks at the End of the Ottoman Empire, eds R.G. Suny, F.M. Göçek, N.M. Naimark, Oxford 2011, s 113-125.

Aktaş F., Mehmet Şükrü pasa ve Edirne savunmasi, [w:] Edirne Eğitim. Dosya: 100. Yilında Balkan Savaslar, ed. S. Sayin, Edirne 2013, s. 31-32.

Alp İ., 1912-1913 Balkan Savaşlarinda Edirne’nin Şükûtu ve Yaşanan Faciâlar, „Karadeniz Araştırmaları" 2018, nr 15/60, s. 1-33.

Erickson E.J., Defeat in Detail. Ottoman Army in the Balkans, 1912-1913, London 2003.

Giza A., Armia butgarska w latach 1875-1913, „Studia i Materiały do Historii Wojskowości" 1989, t. 32, s. 177-196.

Hall R.C., The Balkan Wars 1912-1913. Prelude to the First World War, London-New York 2005.

JSZ [J. Szepietowska], Adrianopol, [w:] Leksykon tradycji butgarskiej, red. A. Naumow, Warszawa 2011, s. 11-12.

Kiliç E., The Balkan war (1912-1913) and visions of the future in Ottoman Turkish literature, Leiden 2015.

Levy A., The Siege of Edirne (1912-1913) as Seen by a Jewish Eyewitness: Social, Political and Cultural Perspectives, [w:] Jews, Turks, and Ottomans: A Shared History, Fifteenth Through the Twentieth Century, ed. idem, Syracuse-New York 2002, s. 153-193.

Macar O.D., Epidemic Diseases on the Thracian Front of the Ottoman Empire during the Balkan Wars, [w:] War and Nationalism. The Balkan Wars, 1912-1913, and Their Sociopolitical Implications, eds M.H. Yavuz, I. Blumi, Salt Lake City 2013, s. 272-297.

Türk Silablı Kuvvetleri Taribi Osmanlı Devri Balkan Harbi (1912-1913) II nci Cilt 3 ncü Kısım Edirne Kalesi Etrafindaki Muharebeler, Ankara 1993.

Wasti S.T., The 1912-13 Balkan Wars and the Siege of Edirne, „Middle Eastern Studies” 2004, vol. 40, no. 4, s. 59-78.

Vachkov A., The Balkan War 1912-1913, Sofia 2005.

Бојевић P., Bојвода Cmena Cmenaнoвић 1856-1929, Чачак 2006 (Bojević R., Vojevoda Stepa Stepanović 1856-1929, Čačak 2006).

Вачева А., Полковник Никола Жеков в подкрепа на истината за Одринската епопея 1913 г., „Военноисторически сборник” 2005, брой 1, s. 52-54 (Weczewa D., Potkownik Nikota Żekow w podkrepa na istinata za Odrinskata epopeja 1913 g., „Woenno-istoriczeski sbornik” 2005, kn 1, s. 52-54).

Аървингов П., Атаката на Одрин. Подосветлението на историята и изкуството, Coфus 1931 (Dyrwingow P., Ataka na Odrin. Pod oswytlenieto na istorijata i izkustwoto, Sofija 1931). 
Елдъров С., Една история за Балканската война, събрана през десетилетията, „Военноисторически сборник” 2007, брой 3, s. 3-6 (Eldyrow S., Edna istorija za batkanskata wojna, sybrana prez desetileijata, „Woenno-istoriczeski sbornik” 2007, broj 3, s. 3-6).

Иванов Н., Балканската война 1912-1913. Аействията на II Армия. Обсада и атака на Одринската крепост, София 1924 (Iwanow N., Batkanskata wojna 1912-1913 god. Dejstwijata na II Armija, obsada i ataka na Odrinskata krepost, Sofija 1924).

Куюмиджиев Б., Пленяването на коменданта на Одринската крепост на 13 март 1913 г., „Военноисторически сборник” 1983, брой 1, s. 97-101 (Kujumdżiew B., Plenjawaneto na komendanta na Odrinskata krepost na 13 mart 1913 g, "Woennoistoriczeski sbornik" 1983, broj 1, s. 97-101).

Криворов И., Плановете на воюващите страни за Първата балканска война 1912-1913 2., „Военноисторически сборник” 2006, брой 4, s. 12-16 (Kriworow I., Planowete na wojuwaszite strani za pyrwata batkanskata wojna 1912-1913, „Woennoistoriczeski sbornik" 2006, broj 4, s. 12-16).

Марков, Г., България в Балканския съюз срешу Османската империя, 1912-1913 г., София 1989.

Миманов Й., Въздушните сили на България през войните 1912-1945, София 2008 (Milanow J., Wyzdusznite wojski na Bytgarija prez wojnite 1912-1945 g., Sofija 2008).

Михов А., Балканската война 1912-1913. Военните действия в Тракия до Чаmалджанското примирие, София 1914 (Michow D., Batkanskata wojna 19121913. Woennit dyjstwija w Trakija do czataldżanskoto primirie, Sofija 1914).

Пенков С.А., Развитие на действията. Аозенградско срешно сражение, [w:] Кратка военна история на България 681/1945, София 1977, s. 241-270 (Penkow S.D., Razwite na dejstwujata. Lozengradsko sreszno srażenie, [w:] Kratka woenna istorija na Bytgarija 681/1945, Sofija 1977, s. 241-270).

Пастухов А., Балканская война 1912-1913 г2., [w:] Малье войны первой половины ХХ века. Балканьь, сост. Б. Аозовский, Санкт Петербург 2003, s. 233-322 (Pastuchow A., Batkanskaja wojna 1912-1913 gg, [w:] Matye wojny perwoj potowiny XX weka. Batkany, red. B. Łozowskij, Sankt Peterburg 2003, s. 233-322).

Ратковић Б., Ђуришић М., Скоко С., Србија и Црна Гора у Балканским ратовима 1912-1913, Београ丸 1972 (Ratković B., Đurišić M., Skoko S., Srbija i Crna Gora u Balkanskim ratovima 1912-1913, Belgrad 1972).

Рябинин, А.А., Балканскал война, [w:] Малье войньь первой половины ХХ века. Балканъl, сост. Б. Аозовский, Санкт Петербург 2003, s. 121-224 (Rjabinin A.A., Balkanskaja wojna, [w:] Matye wojny perwoj potowiny XX weka. Batkany, red. B. Eozowskij, Sankt Peterburg 2003, s. 121-224).

Фичев, И., Балканската война 1912-1913. Преживелици, бележки и документи, София 1940 (Ficzew I., Batkanskata wojna 1912-1913. Preżiwielici, beleżki i dokumenti, Sofija 1940). 
Христов А., Кратка историяна Освободителната война 1912-1913 година, София 1946 (Christow A., Kratka istorija na oswobodidelnata wojna 1912-1913 godina, Sofija 1946).

Цураков А., Енииклопедия правителствата на България. Хронология на политическия живот 1879-2005, София 2005 (Curakow A., Enciklopedija pravitelstwata na Butgarija. Chronologijana politiczesija żiwot 1879-2005, Sofija 2005).

\section{Dariusz Faszcza}

\section{SIEGE OF ADRIANOPOL DURING THE FIRST BALKAN WAR (1912-1913)}

Summary. Every war is evil, bringing death, suffering, expulsion and havoc. During the two Balkan wars of 1912-1913, such events also took place, which on the one hand were characterized by a considerable intensity and variety of forms of military operations, and on the other hand, by unprecedented cruelty against civilians. The aim of the article is to present the conditions in which the defense of Adrianople was carried out during the First Balkan War. To achieve this goal, it was necessary to discuss the military significance of the Adrianople fortress and the course of siege, taking into account the situation of civilian population in besieged city.

Keywords: Adrianopol, First Balkan War, Şükrü pasha, civilian population 